\title{
PENGARUH HERDING DAN OVERCONFIDENCE TERHADAP KEPUTUSAN INVESTASI \\ (Studi Pada Nasabah Emas Kantor Pegadaian Ungaran)
}

\author{
Istiqomah Nur Aristiwati ${ }^{1}$, Suryakusuma Kholid Hidayatullah ${ }^{2}$ \\ Program Studi Manajemen, STIE Bank BPD Jateng \\ 1) istiqonuraris@gmail.com \\ Program Studi Manajemen, STIE Bank BPD Jateng \\ ${ }^{2)}$ suryakusumakh7@gmail.com
}

\begin{abstract}
ABSTRAK
Keputusan investasi merupakan kebijakan dalam pengalokasian dana kedalam bentuk- bentuk investasi yang menguntungkan dengan memiliki dimensi waktu jangka panjang, sehingga keputusan yang diambil harus dipertimbangkan dengan baik, karena memiliki konsekuensi berjangka panjang pula. Perilaku investor dalam mengambil keputusan investasi seringkali dipengaruhi oleh beberapa faktor psikologis seperti faktor sosial dan faktor kognitif yang menyebabkan tindakan investor menjadi irasional. Penelitian ini dilakukan untuk menganalisis pengaruh herding dan overconfidence terhadap keputusan investasi emas dengan objek penelitian pegadaian cabang pembantu ungaran. Sebanyak 96 nasabah tabungan emas Pegadaian Cabang Pembantu Ungaran dipilih sebagai sampel dengan teknik accidental sampling. Teknik analisis data dalam penelitian ini menggunakan analisis regresi linier berganda. Hasil penelitian ini menunjukan bahwa variabel overconfidence memiliki pengaruh positif dan signifikan terhadap keputusan investasi emas. Sedangkan untuk variabel herding berpengaruh positif dan tidak signifikan terhadap keputusan investasi emas.
\end{abstract}

Kata kunci: Herding, overconfidence, keputusan investasi.

\section{PENDAHULUAN}

Setiap orang tentunya ingin memiliki kehidupan yang layak dan baik di masa mendatang. Beberapa diantaranya telah memikirkan upaya upaya apa saja yang perlu dilakukan agar kehidupannya tetap layak dimasa mendatang. Salah satu upaya untuk memenuhi hasrat tersebut adalah dengan melakukan investasi. Investasi merupakan konsumsi yang ditunda atau ditahan sementara waktu dan akan dikonsumsi kembali diwaktu yang akan datang bahkan dengan jumlah yang lebih besar. Dengan adanya aktivitas investasi, seorang investor pasti akan melakukan pengambilan keputusan pada investasinya karena dua hal tersebut memanglah saling berkaitan. Keputusan investasi merupakan sebuah tindakan atau kebijakan yang dipilih dalam berinvestasi guna mendapatkan return yang bersifat menguntungkan dimasa yang akan datang (Wulandari dan Iramani, 2014). Dijaman yang modern ini, investasi merupakan salah satu kebutuhuan penting. Hal ini disebabkan karena investasi dapat membantu kebutuhan investor di masa mendatang. Selain itu, investasi juga dapat melindungi nilai aset yang dimiliki dari efek inflasi yang kian meningkat. Keberhasilan seorang investor dalam berinvestasi pada dasarnya dapat ditentukan oleh seberapa tepat keputusan yang diambil. Serta ditentukan oleh kemampuan dalam menentukan jenis maupun waktu investasi yang memiliki kemungkinan lebih besar untuk mendapatkan keuntungan (return). 
Keberhasilan seorang investor ditentukan oleh seberapa tepat keputusan yang diambil dan seberapa mampu investor tersebut menentukan dengan baik jenis maupun waktu investasinya. Namun ditengah kondisi ketidakpastian yang tinggi karena virus corona saat ini, investor dituntut untuk bersikap lebih berhati-hati dalam mengambil keputusan investasinya, mulai dari memilih instrumen investasi yang tepat hingga mempertimbangkan tolerance risk agar senantiasa meraih keuntungan (return). Pandemi ini telah menekan pasar finansial di hampir seluruh dunia, termasuk Indonesia dan menyebabkan kondisi perekonomian global menjadi tidak stabil. Ketidakstabilan perekonomian ini, mempengaruhi aset-aset beresiko seperti saham. Instrumen investasi dengan tingkat risiko tinggi seperti saham justru akan merugikan investor saat ini karena nilainya yang cenderung turun. Pemilihan instrumen investasi yang stabil dan memiliki kinerja positif adalah hal yang semesetinya dilakukan oleh investor, agar investasinya tetap aman dan tidak mengalami kerugian di masa krisis seperti saat ini. Investasi dengan kinerja yang positif diartikan dengan nilai dari suatu instrumen investasi yang tidak mengalami penurunan terlalu tajam. Salah satu investasi yang aman dilakukan saat pandemi ini adalah dengan berinvestasi pada aset safe haven seperti emas. Aset safe haven adalah instrumen investasi yang tidak mudah terpengaruh oleh gejolak dipasar keuangan. Emas merupakan instrumen yang memiliki tingkat likuiditas tinggi dan harganya relatif stabil, bahkan cenderung meningkat dari tahun ke tahun serta nilai emas tidak tergerus inflasi dalam jangka waktu yang lama. Hal ini menjadikan emas sebagai aset safehaven dan tabungan jangka panjang yang aman.

Sepanjang tahun 2020, harga logam mulia Antam mengalami peningkatan hingga $55 \%$, dibandingkan pada akhir tahun lalu. Harga emas terus-menerus menembus rekor terutama setelah pandemi Covid-19 melanda. Bahkan sudah melampaui Rp 1 juta per gram pada pertengahan tahun 2020. Bahkan pada akhir tahun 2010 atau 10 tahun yang lalu, harga emas batangan antam hanya berkisar Rp 410.000 per gram. Artinya dalam 10 tahun terakhir harga logam mulia Antam sudah naik 155\% atau naik 2,5 kali lipat (www.bareksa.com).

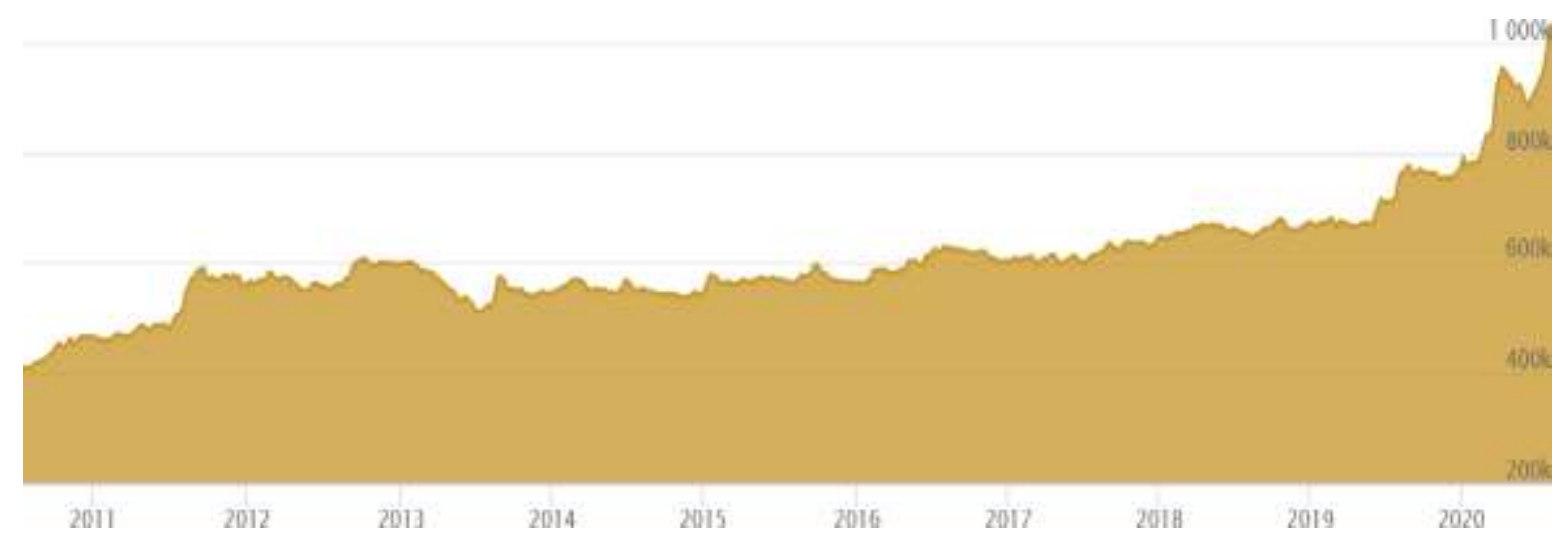

Gambar 1 Pergerakan Harga Emas Antam dalam 10 Tahun

Kenaikan harga emas dimasa pandemi ini, diiringi dengan kenaikan jumlah transaksi emas di pegadaian. Seperti yang dilansir pada kontan.co.id bahwa jumlah pembukaan rekening tabungan emas yang tercatat di PT Pegadaian (Persero) mengalami kenaikan yang cukup signifikan dibanding pada tahun lalu. PT Pegadaian (Persero) mencatat sebanyak 55.955 rekening tabungan emas per 30 Juni 2020. Jumlah ini naik sekitar 174,24\% jika dibandingkan tahun 2019 lalu. Sementara itu, volume transaksi pada tabungan emas per 30 Juni juga mengalami peningkatan sebesar 237.282 gram, 
sedangkan pada tahun lalu hanya berkisar 219.689 gram yang berarti mengalami peningkatan sebesar $8,01 \%$. Volume transaksi pada emas batangan juga mengalami kenaikan yang sangat signifikan sebesar 374,03\%, yakni pada tahun 2019 hanya berjumlah 9.858 gram menjadi sebesar 46.728 gram per 30 Juni 2020.

Tabel 1 : Jumlah Pendapatan Penjualan Emas di Pegadaian

Tahun Jumlah Pendapatan Penjualan Emas Persentase

\begin{tabular}{lrc}
\hline $\mathbf{2 0 1 7}$ & Rp 304.640 & - \\
$\mathbf{2 0 1 8}$ & Rp 1.349 .870 & $343,10 \%$ \\
$\mathbf{2 0 1 9}$ & Rp 4.505 .422 & $233,78 \%$ \\
$\mathbf{2 0 2 0}$ & Rp 5.174 .487 & $14,85 \%$ \\
\hline
\end{tabular}

Sumber : Laporan Tahunan PT Pegadaian (Persero)

Berdasarkan data diatasmenunjukan bahwa, jumlah pendapatan penjualan emas di Pegadaian mengalami peningkatan pada setiap tahunnya. Kenaikan pendapatan yang sangat signifikan terjadi pada tahun 2018. Jumlah pendapatan penjualan emas tahun 2018 adalah sebesar Rp1.349.870 juta, dan meningkat 343,10\% atau Rp1.045.230 juta dibanding tahun 2017 yakni sebesar Rp304.640 juta. Sedangkan pada tahun 2019, mengalami peningkatan sebesar $233,77 \%$ atau Rp3.155.552 juta dibanding tahun sebelumnya, yaitu dari Rp1.349.870 juta pada tahun 2018 menjadi Rp4.505.422 juta di tahun 2019. Dan pada triwulan III 2020 pendapatan penjualan emas juga meningkat 14,85\% dari Rp4.505.422 menjadi Rp5.174.487 per 30 September 2020.

Hal ini sesuai juga dengan data yang diperoleh dari Kantor Pegadaian Ungaran sebagai objek dari penelitian ini. Yang mencatat bahwa pada tiga tahun terakhir, jumlah investor emas di Kantor Pegadaian Ungaran mengalami kenaikan yang cukup signifikan dimana tahun 2017 jumlah investor sebanyak 2.598 orang hingga akhir tahun 2020 jumlah investor naik empat kali lipat yakni sebanyak 10.722 orang. Kenaikan jumlah investor yang pesat tahun 2020 pada Kantor Pegadaian Ungaran disebabkan oleh upaya dari pihak Pegadaian, yang melakukan langkah-langkah edukasi untuk masyarakat melalui webinar yang diantaranya membahas mengenai investasi emas. Selain itu adanya kemudahan transaksi secara aman melalui platform Pegadaian digital maupun platform lainnya yang bekerja sama dengan Pegadaian, sehingga memudahkan masyarakat dalam memulai investasi emas bahkan dengan nominal yang kecil. Hal ini menunjukan bahwa animo masyarakat terhadap emas semakin meningkat seiring dengan kenaikan harga emas itu sendiri. Mayarakat lebih memilih mengalihkan depositonya untuk menabung emas di masa yang penuh ketidakpastian seperti saat ini. Dikarenakan masyarakat semakin khawatir dengan prospek ekonomi ke depan, pasalnya jumlah khasus virus Corona kian bertambah dan mencetak rekor-rekor baru, sementara aktivitas ekonomi justru tersendat. Sehingga menyebabkan kekhawatiran masyarakat untuk berinvestasi di aset-aset beresiko seperti saham dan obligasi, maka hal ini lah yang menjadikan investor beralih pada aset savehaven seperti emas yang tidak mudah terpengaruhi oleh gejolak dipasar keuangan.

Setiap investor dalam mengambil suatu keputusan investasi akan berbeda dengan investor lainnya. Hal ini disebabkan terdapat faktor psikologi yang mempengaruhi masing- masing keputusan investor sehingga terdapat perbedaan antara investor satu dengan investor lainnya dalam konteks mengambil keputusan investasi. Menurut Wulandari \& Iramani (2014) mengungkapkan bahwa perilaku investor yang setiap saat dapat berubah-ubah adalah pengaruh dari faktor psikologinya. Terdapat unsur subyektivitas, emosi, dan faktor psikologi lain yang justru lebih dominan dalam 
mempengaruhi bahkan memaksa seorang investor untuk memilih jenis investasi apa yang akan mereka pilih. Faktor psikologis tersebut mempengaruhi perilaku investor dalam berinvestasi dan hasil yang akan dicapainya nanti. Sebuah studi yang mepelajari tentang investasi dengan menggunakan ilmu psikologi dan ilmu keuangan dikenal dengan istilah perilaku keuangan (Behavioral Finance).

Investor tidak selalu berfikir rasional dalam pengambilan suatu keputusan investasi. Menurut Santoso (2009) dalam Setiawan et al,. (2018) menyatakan bahwa faktor psikologi dalam diri investor serta adanya pengaruh sosial akan mempengaruhi pengambilan keputusan investasinya menjadi tidak rasional. Adanya faktor sosial yang mempengaruhi seorang investor dalam hal mengambil keputusan salah satunya adalah perilaku Herding. Herding merupakan perilaku investor yang irasional dengan kecenderungan mengikuti keputusan investor lain dalam berinvestasi. Investor irasional membuat keputusan yang sama dengan orang lain atau sekelompok orang mengenai pemilihan jenis investasi atau bahkan transaksi pembelian dan penjualan instrumen investas. Namun investor yang rasional tidak mengikuti aliran massa atau keputusan dari yang merupakan penyebab utama pasar yang efisien. Perilaku Herding ini lah yang membuat pasar tidak efisien sehingga mengarahkan pasar ke arah gelembung spekulatif di pasar (Anum and Ameer 2017). Gelembung spekulatif adalah situasi pasar dimana spekulasi spekulasi yang ditimbulkan dari beberapa orang mengakibatkan kenaikan antusiasme investor. Hal ini menjelaskan bahwa pada dasarnya gelembung spekulasi di pasar bersumber dari psikologi dan emosi investor di mana keyakinan mereka terlalu berlebihan tentang terjadinya suatu hal. Hal ini dipicu oleh adanya efek penularan dan saling meniru antar investor yang satu dengan investor lain, yang menyebabkan gelembung menjadi semakin besar(Asri 2015). Hasil dari penelitian Afriani dan Halmawati (2019) menyatakan bahwa seorang investor akan menunjukkan perilaku herding ketika ia lebih bergantung pada informasi yang divalidasi oleh orang banyak, bukan pada penilaian sendiri karena dengan persepsi bahwa pilihan atau keputusan investasi yang diambil mayoritas tidak mungkin salah. Peneliti anter sebut sesuai dengan temuan Danepo (2018) tentang pengaruh bias perilaku investor terhadap keputusan investasi, yang menunjukkan bahwa perilaku herding berpengaruh positif dan signifikan terhadap keputusan investasi. Hasil ini dapat dimaknai bahwa semakin besar perilaku herding yang dimiliki investor maka akan mempengaruhi keputusan investasinya. Namun hasil berbeda ditunjukan oleh penelitian Setiawan et al,. (2018) yang menyatakan Herding tidak berpengaruh terhadap keputusan investasi, karena dengan adanya ketersediaan informasi yang cukup, investor akan menggunakan informasi tersebut sebagai dasar untuk pengambilan keputusan investasi.

Sebagian investor cenderung mengalami overconfidence dalam pengambilan keputusan. Teori ini didukung oleh temuan Budiarto dan Susanti (2017) dan Pradhana (2018) yang menyatakan bahwa investor dengan overconfidence yang tinggi akan lebih berani dalam mengambil keputusan, sementara yang overconfidence rendah cenderung berhati-hati dalam membuat keputusan. Hal berbeda diungkapkan oleh Afriani dan Halmawati (2019) dan Sarimatua (2017) yang mengatakan bahwa, walaupun investor memiliki overconvidence yang tinggi karena mereka merasa mempunyai pengetahuan yang cukup tentang saham, namun jika belum memiliki kemampuan yang cukup mahir dalam praktik bertransaksi saham sebagai investor yang profesional, maka investor tersebut masih menganggap saham adalah investasi yang sangat beresiko. Sehingga dalam penelitian ini, menyatakan bahwa tingkat overconfidence tidak akan berpengaruh 
dalam pengambilan keputusan investasi, jika tidak diimbangi dengan kemampuan dan pengalaman yang mumpuni dalam berinvestasi.

Perilaku investor dalam mengambil keputusan investasi dapat dipengaruhi oleh beberapa faktor, seperti faktor kognitif dan faktor sosial yang menyebabkan tindakan investor menjadi irasional (Setiawan et al,. 2018). Faktor kognitif seperti overconfidence akan membuat investor kurang peka dan tidak dapat menerjemah suatu informasi dengan tepat serta faktor sosial seperti herding yang membuat investor tidak dapat menentukan keputusannya sendiri dan cenderung mengikuti keputusan orang lain. Faktor kognitif dan sosial tersebut dapat mempengaruhi keputusan investor, karena dengan kondisi ketidakpastian yang tinggi akibat virus Corona saat ini, menyebabkan investor cenderung berperilaku bias dalam pengambilan keputusan investasinya. Atas dasar tersebut, penelitian ini dilakukan untuk mengidentifikasi pengaruh herding dan overconfidence terhadap keputusan investasi. Penelitian ini penting dilakukan karena untuk memberikan gambaran bagi investor agar memahami bias-bias perilaku dalam pengambilan keputusan, sehingga tidak salah dalam mengambil keputusan ketika berinvestasi. Karena apabila bias-bias tersebut tidak diperhatikan dan dikelola dengan baik maka dapat merugikan investor itu sendiri. Penelitian terkait keputusan investasi yang melibatkan dua aspek yakni herding dan over confidence masih menunjukan beberapa hasil yang berbeda atau berkontradikasi, sehingga terdapat masih research gap

\section{LANDASAN TEORI DAN PENGEMBANGAN HIPOTESIS (JIKA ADA)}

\section{Landasan Teori}

\section{Behavioral Finance atau Perilaku Keuangan}

Behavioral finance atau Perilaku Keuangan yaitu sebuah studi yang menjelaskan tentang dampak factor kognitif dan emosi yang mampu mempengaruhi pengambilan keputusan keuangan (Afriani dan Halmawati 2019). Perilaku Keuangan (behavioral finance) merupakan teori yang membahas terkait sikap seseorang dalam berfikir, mempertimbangkan, dan membuat suatu keputusan.Seorang investor dalam menanggapi atau mengambil suatu keputusan terkadang menyimpang dalam perilakunya maupun dalam pengambilan keputusannya, hal tersebut dipengaruhi oleh bias-bias perilaku (Ramdani 2018). Dalam behavioral finance suatu keputusan dapat dilandasi berbagai aspek yang dapat menimbulkan bias. Mulai dari emosi, sifat, kesukaan dan lain sebagainya yang tentunya terdapat pada masing-masing individu sebagai makhluk berakal dan makhluk sosial. Bias-bias inilah yang mempengaruhi keputusan investor untuk bertindak secara tidak rasional dalam konteks pengambilan keputusan keuangannya (Pradikasari dan Isbanah 2018).

\section{Keputusan Investasi}

Keputusan Investasi adalah suatu kebijakan yang diambil untuk mengalokasikan dana yang dimiliki pada suatu aset guna mendapatkan keuntungan dimasa yang akan datang. Keputusan investas juga dapat diartikan sebagai penentuan seseorang dalam mengalokasikan dananya kedalam bentuk - bentuk investasi yangakan mendatangkan keuntungan dimasa depan (Wulandari dan Iramani 2014). Menurut Ramdani (2018) keputusan investasi memiliki dimensi waktu jangka panjang, sehingga keputusan yang diambil harus dipertimbangkan dengan baik, karena memiiki konsekuensi berjangka panjang pula. Keputusan investasi yang demikian sering disebut sebagai capital budgeting yakni keseluruhan proses perencanaan serta pengambilan keputusan mengenai 
pengeluaran dana dengan jangka waktu kembalinya dana tersebut lebih dari satu tahun atau berjangka panjang.

\section{Herding}

Herding diistilahkan sebagai suatu perilaku investor yang berkecenderungan untuk mengikuti tindakan investor lainnya (Ramdani 2018). Menurut Setiawan et al,.(2018) Perilaku Herding merupakan bias perilaku yang paling umum terjadi dimana investor cenderung mengikuti keputusan investasi yang diambil oleh mayoritas. Alasan utama herding adalah tekanan atau pengaruh oleh rekan-rekan atau orang-orang sekitar. Herding memberikan hasil yang berisiko karena investor akan cenderung mengabaikan kepercayaan akan kemampuan yang dimilikinya dan cenderung mengikuti tindakan investor lain, pilihan mayoritas orang, maupunpakarinvestasi. Perilaku herding ini merupakan tindakan irasional dimana investor dalam keputusan investasinya tidak berdasarkan pada informasi yang tersedia maupun dari nilai fundamental perusahaan, melainkan berdasarkan tindakan investor lain (Setiawan et al., 2018)

\section{Overconfidence}

Overconfidence adalah perasaan terlalu percaya pada diri sendiri dalam konteks pengambilan keputusan investasi (Novari 2013). Overconfidence menunjuk pada penilaian seseorang investor terhadap dirinya sendiri. Dalam konteks ini investor menilai dirinya mempunyai kemampuan diatas rata-rata (Asri 2015). Perilaku ini dapat berakibat buruk bagi investor pada saat melakukan tindakan investasi. Karena perilaku overconfidence membuat seseorang memilki kepercayaan diri yang sangat tinggi sehingga cenderung overestimate terhadap kemampuannya untuk mengevaluasi jenis investasi yang potensial dan lebih underestimate terhadap resiko yang mungkin terjadi, sehingga berkecenderungan untuk terus melakukan perdagangan atau sering disebut overtrading (Wulandari dan Iramani 2014).

\section{Pengembangan Hipotesis}

\section{Pengaruh Herding terhadap Keputusan Investasi}

Seorang investor yang cenderung memiliki perilaku herding lebih tinggi, akan sering untuk mengikuti investor lain atau kelompok investor yang lebih besar dalam pengambilan keputusan investasi (Ramdani 2018). Perilaku herding merupakan irasional yang dimana investor tidak mendasarkan keputusan investasinya pada informasi yang tersedia ataupun nilai fundamental, melainkan berdasarkan tindakan investor lain atau berdasarkan pilihan terbanyak. Tingginya herding pada diri investor akan berdampak terhadap tingginya keputusan investasi yang didasarkan pada perilaku yang meniru keputusan orang atau pun kelompok lain. (Kumar and Goyal 2015). Hal tersebut didukung penelitian Ramdani (2018) dan Afriani \& Halmawati (2019), yang menyatakan bahwa herding berpengaruh signifikan positif terhadap keputusan investasi.

\section{$H_{1}$ : Herding berpengaruh positif dan signifikan terhadap keputusan investasi.}

\section{Pengaruh Overconfidence terhadap Keputusan Investasi}

Investor dengan overconfidence yang tinggi merasa pengetahuan atau informasi yang dimilikinya mampu ia gunakan dengan baik karena memilki kemampuan dalam menganalisis dengan tepat dan akurat (Asri 2015). Namun sebenarnya hal ini merupakan suatu ilusi, karena overconfidence menyebabkan seseorang salah menafsirkan suatu informasi dan menjadi terlalu yakin pada kemampuan menganalisa informasi tersebut. Hal tersebut akan menyebabkan investor mengambil keputusan yang tidak tepat, sehingga berdampak pada tindakan yang akan dilakukan, resiko yang diambil serta kerugian pada investasi yang dimiliki (Nofsinger 2016). Menurut Baker dan Nofsinger (2002) dalam 
Jannah dan Ady (2017) seorang investor yang memiliki tingkat overconfidence yang tinggi akan cenderung overestimate terhadap pengetahuan yang dimiliki, yang mengestimasikan bahwa akan mendapatkan keuntungan lebih besar dalam melakukan investasi. Hal tersebut didukung penelitian Setiawan et al,. (2018) dan Pradikasari dan Isbanah (2018), yang menyatakan bahwa perilaku overconfidence berpengaruh positif dan signifikan terhadap keputusan investasi.

$\mathrm{H}_{2}$ : overconfidence berpengaruh positif dan signifikan terhadap keputusan investasi

\section{MODEL PENELITIAN}

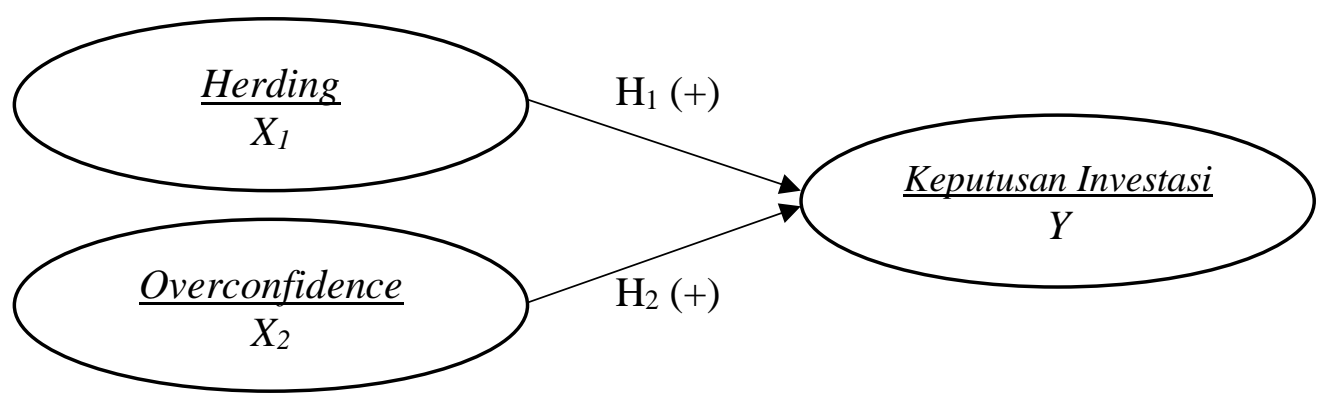

\section{Gambar 2 Model Penelitian}

\section{METODE PENELITIAN}

\section{Jenis dan Sumber Data}

Dalam penelitian ini menggunakan jenis penelitian kuantitatif, dimana semua data dan informasi dalam penelitian ini bersumber dari data primer. Data primer yaitu data yang diperoleh secara langsung dari responden. Data tersebut dikumpulkan dengan menggunakan metode kuesioner yang didistribusikan langsung kepada responden dengan pemberian angket pada setiap nasabah emas yang mendatangi Kantor Pegadaian Ungaran dalam kurun waktu yang telah ditentukan pihak Pegadaian yaitu tanggal 7 November-14 november 2020.Pegukuran data menggunakan skala Likert 5 jenjang skala dari angka 1 sampai angka 5, yaitu: (1) Sangat tidak setuju (STS); (2) Tidak setuju (TS); (3) Netral (N); (4) Setuju (S); (5) Sangat setuju (SS). Dengan skala likert, maka varibel yang akan diukur dijabarkan menjadi indikator variabel. Kemudian, indikator tersebut dijadikan sebagai titik tolak untuk menyusun item-item instrumen yang dapat berupa pertanyaan atau pernyataan (Ramdani 2018).

\section{Populasi dan Sampel}

Populasi adalah wilayah generalisasi yang terdiri dari obyek/subyek yang memiliki kualitas dan karakteristik tertentu untuk dipelajari dan selanjutnya dapat ditarik kesimpulan(Sugiyono 2013). Populasi yang dipilih dalam penelitian ini adalah nasabah tabungan emas di Pegadaian Cabang Pembantu Ungaran.

Sampel adalah komponen dari jumlah dan karakteristik yang ada pada populasi (Barlian 2016). Apabila populasi terlalu besar dan tidak memungkinkan untuk mempelajari semua yang ada pada populasi, misalnya keterbatasan dana, tenaga, dan waktu, maka dapat menggunakan sampel yang diambil dari pupulasi tersebut. Untuk itu hal yang telah dipelajari dari sampel tersebut, kesimpulannya akan dapat diberlakukan untuk populasi yang telah ditetapkan sebelumnya (Sugiyono 2013).

Teknik sampling adalah teknik pengambilan sampel yang digunakan untuk menentukan sampel yang akan digunakan dalam sebuah penelitian. Untuk teknik 
pengambilan sampel dalam penelitian ini menggunakan accidental sampling atau sampling aksidental yaitu teknik penentuan sampel berdasarkan kebetulan dimana siapa saja yang secara kebetulan ditemui dapat digunakan sebagai sampel, apabila dipandang orang yang kebetulan ditemui tersebut cocok sebagai sumber data (Sugiyono 2013). Dalam teknik aksidental, pengambilan sampel tidak ditetapkan terlebih dulu. Sehingga langsung mengumpulkan data dari unit sampling yang ditemui. Menurut Sugiyono (2013) penentuan ukuran sampel menggunakan teori yang dikembangkan dari Isaac dan Michaeldengan rumus sebagai berikut :

$n=\frac{\left(\frac{Z \alpha}{2}\right)^{2}}{e^{2}}$

Keterangan :

$\mathrm{n}=$ ukuran sampel

$\mathrm{Z}=$ tingkat kepercayaan/signifikansi

$\mathrm{e}=$ margin oferror $5 \%$ (Kesalahan pengambilan sampel yang ditolerir)

$\alpha=1$ - tingkat signifikansi

$n=\left(\frac{(\mathbf{1}, \mathbf{9 6}) \times(\mathbf{0}, \mathbf{2 5})}{0,05}\right)^{2}$

$n=96,04$

Dengan tingkat keyakinan $95 \%$ atau $\mathrm{Z}=1,96$ dan e $=0,05$. Maka jumlah sampel yang diambildalam penelitian ini adalah sebagai berikut. Hasil perhitungan menunjukan minimal sampel adalah 96,04 reponden atau dibulatkan menjadi 96 responden. Sampel tersebut didistribusikan kepada responden yang memilikitabungan emas di Pegadaian Cabang Pembantu Ungaran.

\section{Definisi Operasional Variabel Penelitian}

Tabel 2 : Definisi Operasional

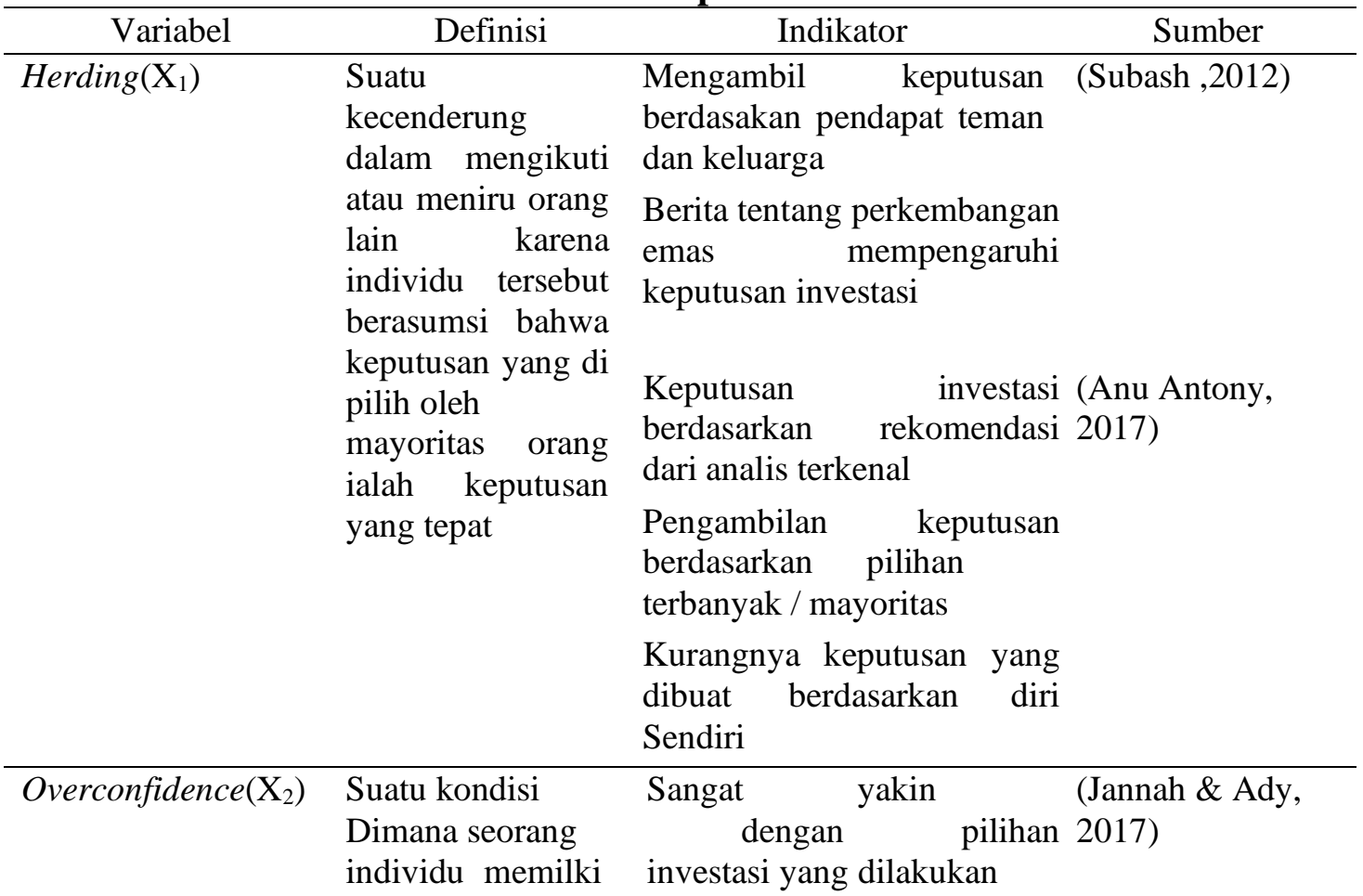




$\begin{array}{llll}\begin{array}{l}\text { sifat percaya diri } \\ \text { yang berlebihan } \\ \text { sehingga } \\ \text { membuatnya } \\ \begin{array}{l}\text { overestimate } \\ \text { terhadap }\end{array}\end{array} & \begin{array}{l}\text { Percaya bahwa dirinyalebih } \\ \text { baik dalamberinvestasi dari } \\ \text { pada orang lain }\end{array} & \\ \begin{array}{l}\text { kemampuannya } \\ \text { dan underestimate }\end{array} & \begin{array}{l}\text { Menilliki keterampilan dan } \\ \text { berinvestasi }\end{array} & \\ & \text { Yakin akan mendapatkan } & \text { (Anu } & \text { Antony } \\ & & & \\ & & & \end{array}$

\section{Teknik Analisis Data}

Dalam research ini, pengolahan data dilakukan dengan bantuan rencana statistical package for social science (SPSS) for windows. Data primer dengan skala ordinal likert yang telah dikumpulkan, teknik analisis yang digunakan dalam peneltian ini adalah analisis regresi linier berganda untuk mengetahui pengaruh variabel independen (herding dan overconfidence) terhadap variabel dependen (keputusan investasi). Analisis regresi linier berganda digunakan karena dalam penelitian ini, jumlah variabel independen lebih dari satu. Agar model analisis yang dihasilkan dinyatakan baik lalu perlu melalui beberapa pengujian yaitu uji validitas, uji reliabilitas, uji asumsi klasik, dan uji goodness of fit. Model persamaan regresi linear dalam riset ini dapat diformulasikan sebagai berikut:

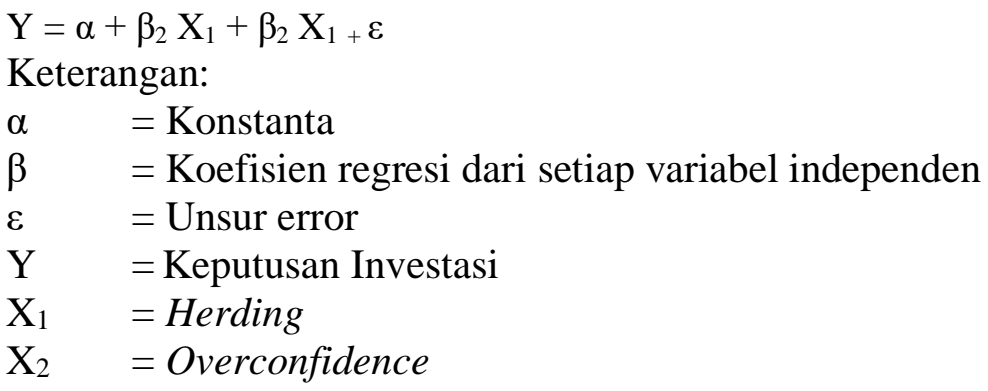

\section{HASIL DAN PEMBAHASAN}

\section{Hasil Pengumpulan Data}

Objek penelitian ini adalah Pegadaian Cabang Pembantu Ungaran, yang beralamat di jalan Diponegoro No.34, Ungaran. Untuk mengetahui gambaran tentang responden dalam penelitian ini maka dapat dijelaskan karakteristik responden dalam penelitian ini sebagai berikut :

Tabel 3 : Jenis Kelamin Responden

\begin{tabular}{ccc}
\hline Jenis Kelamin & Frekuensi & Persentase \\
\hline Laki-laki & 31 & 32,0 \\
Perempuan & 65 & 67,0 \\
\hline Total & $\mathbf{9 6}$ & $\mathbf{1 0 0 , 0}$
\end{tabular}

Dalam penelitian ini perempuan lebih banyak melakukan investasi sebesar $67 \%$ dibanding dengan laki-laki. Hal ini dikarenakan, emas merupakan sesuatu yang diminati oleh wanita untuk memperindah penampilannya. Namun saat ini wanita cenderung membeli emas sebagai bentuk investasi yang mudah dicairkan dan nilainya tidak mudah dipengaruhi oleh gejolak pasar. Dalam memilih instrumen investasi, perempuan cenderung konservatif. Mereka lebih suka main aman agar resiko yang ditimbulkan lebih rendah. 
Tabel 4 : Latar Belakang Pendidikan Responden

\begin{tabular}{ccc}
\hline Pendidikan & Frekuensi & Persentase \\
\hline SD/SMP/SMA & 43 & 44,3 \\
Diploma & 9 & 9,3 \\
Sarjana & 44 & 45,4 \\
Magister & 0 & 0,0 \\
\hline Total & $\mathbf{9 6}$ & $\mathbf{1 0 0 , 0}$ \\
\hline
\end{tabular}

Berdasarkan tabel 4 menunjukan bahwa pada penelitian ini paling banyak responden yakni sebesar 45,4 \% responden berpendidikan sarjana. Hal ini berarti bahwa tingkat pendidikan seseorang juga mempengaruhi keputusan sesorang dalam mengelola keuangannya. Mereka tahu bagaimana mengalokasikan dana yang mereka miliki dengan baik, seperti melakukan investasi di aset save haven emas ini.

Tabel 5 : Pekerjaan Responden

\begin{tabular}{ccc}
\hline Pekerjaan & Frekuensi & Persentase \\
\hline PNS & 13 & 13,4 \\
Wiraswasta & 19 & 19,6 \\
Swasta & 36 & 37,1 \\
Pelajar/Mahasiswa & 18 & 18,6 \\
Lainnya & 10 & 10,3 \\
\hline Total & $\mathbf{9 6}$ & $\mathbf{1 0 0 , 0}$
\end{tabular}

Berdasarkan data responden, investor emas yang bekerja sebagai karyawan swasta lebih mendominasi yakni sebesar 37, 1\% . Hal ini berarti bahwa karyawan swasta telah mengalokasikan pendapatan mereka dengan baik ke pos-pos anggaran tertentu. Dan salah satunya menganggarkan pendapatannya kedalam investasi emas ini.

Tabel 6 : Sumber Informasi Responden

\begin{tabular}{ccc}
\hline Sumber & Frekuensi & Persentase \\
\hline Media Sosial & 43 & 44,3 \\
Internet & 33 & 34,0 \\
Televisi & 3 & 3,1 \\
Media Cetak & 4 & 4,1 \\
Saudara/Teman & 13 & 13,4 \\
\hline Total & $\mathbf{9 6}$ & $\mathbf{1 0 0 , 0}$ \\
\hline
\end{tabular}

Berdasarkan tabel 6 menunjukan bahwa mayoritas responden dalam mencari informasi seputar investasi emas adalah bersumber pada media sosial dan internet. Seperti yang telah diketahui bahwa internet memberikan banyak informasi secara meluas terkait suatu hal. Investor menggunakan media sosial yang mereka miliki untuk mendapatkan informasi yang mereka butuhkan seputar investasi emas, dan investor bebas berselancar di internet guna mendapat informasi yang paling valid terkait investasi emas. 
Hasil Uji Validitas dan Reliabilitas

Tabel 7 : Hasil Uji Validitas

\begin{tabular}{ccccc}
\hline Variabel & Atribut & R tabel & R hitung & Keterangan \\
\hline Herding & H 1 & 0,201 & 0,535 & VALID \\
& H 2 & 0,201 & 0,690 & VALID \\
& H 3 & 0,201 & 0,796 & VALID \\
& H 4 & 0,201 & 0,730 & VALID \\
& H 5 & 0,201 & 0,752 & VALID \\
\hline Overconfidence & OV 1 & 0,201 & 0,659 & VALID \\
& OV 2 & 0,201 & 0,631 & VALID \\
& OV 3 & 0,201 & 0,663 & VALID \\
& OV 4 & 0,201 & 0,701 & VALID \\
& OV 5 & 0,201 & 0,741 & VALID \\
\hline Keputusan Investasi & KI 1 & 0,201 & 0,784 & VALID \\
& KI 2 & 0,201 & 0,676 & VALID \\
& KI 3 & 0,201 & 0,636 & VALID \\
& KI 4 & 0,201 & 0,717 & VALID \\
& KI 5 & 0,201 & 0,693 & VALID \\
\hline
\end{tabular}

Berdasasarkan tabel 7 menunjukkan bahwa seluruh item pernyataan yang ada pada masing-masing variabel dapat dinyatakan valid karena $\mathrm{R}$ hitung lebih besar dari $\mathrm{R}$ tabel, dengan demikian seluruh butir pernyataan pada masing-masing variabel dapat digunakan untuk mengukur data secara tepat.

Tabel 8 : Hasil Uji Reliabilitas

\begin{tabular}{lcccc}
\hline \multicolumn{1}{c}{ Variabel } & $\begin{array}{c}\text { Jumlah } \\
\text { Pernyataan }\end{array}$ & $\begin{array}{c}\text { Cronbach's } \\
\text { Alpha }\end{array}$ & $\begin{array}{c}\text { Batas } \\
\text { Minimum }\end{array}$ & Keterangan \\
\hline Herding & 5 & 0,742 & 0,700 & Reliabel \\
Overconfidence & 5 & 0,715 & 0,700 & Reliabel \\
Keputusan Investasi & 5 & 0,746 & 0,700 & Reliabel \\
\hline
\end{tabular}

Berdasarkan hasil uji pada tabel 8 dapat disimpulkan bahwaseluruh variabel penelitian dapat dikatakan reliabel, karena nilai koefisien Cronbach's Alpha lebih dari 0,700. Oleh sebab itu dapat disimpulkan bahwa item pertanyaan reliabelserta penilaian responden terhadap pernyataan adalah konsisten dari waktu ke waktu. Sehingga kuesioner dari variabel- variabel tersebut dapat digunakan sebagai instrumen untuk penelitian selanjutnya. 


\section{Hasil Uji Asumsi Klasik Hasil Uji Normalitas}

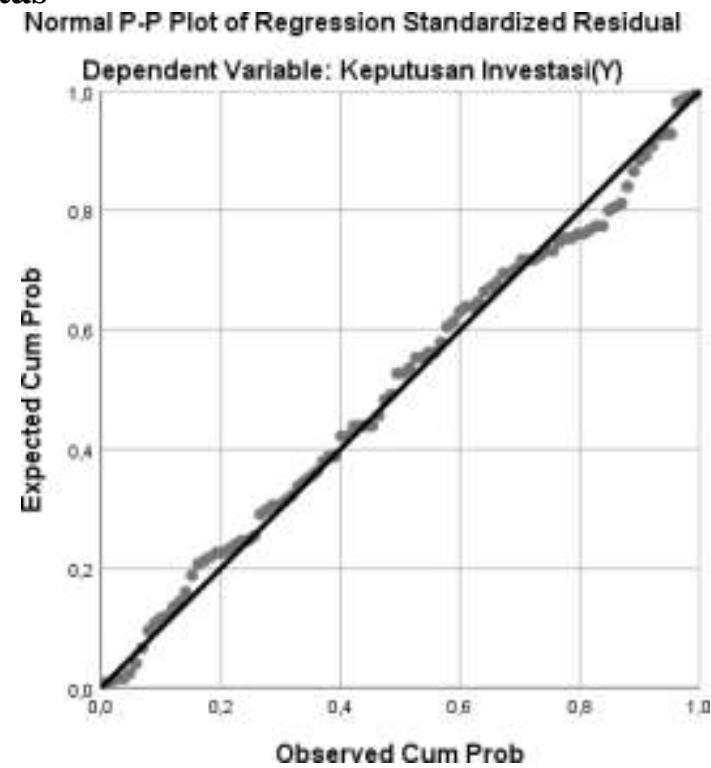

Gambar 3 Hasil Uji Normalitas

Grafik plot pada uji normalitasdiatas, memperlihatkan titik-titik mengikuti dan mendekati garis diagonalnya, sehingga dapat dikatakan menuju asumsi normal atauberdistribusi normal. Dengan demikian, maka variabel keputusan investasi (Y) dapat memenuhi asumsi normal dalam uji normalitas ini.

\section{Hasil Uji Multikolinearitas}

Tabel 9 : Hasil Uji Multikolinearitas

\begin{tabular}{lcc}
\hline \multicolumn{1}{c}{ Variabel } & \multicolumn{2}{c}{ Collinearity Statistics } \\
\cline { 2 - 3 } & Tolerance & VIF \\
\hline Herding $\left(\mathrm{X}_{1}\right)$ & 0,998 & 1,002 \\
Overconfidence $\left(\mathrm{X}_{2}\right)$ & 0,998 & 1,002 \\
\hline
\end{tabular}

a. DependentVariable: Keputusan Investasi(Y)

Berdasarkan hasil pengujian pada tabel 9, menunjukan bahwa nilai tolerance dari kedua variabel independen sebesar 0,998 dimana lebih besar dari 0,10 dan nilai VIF sebesar 1,002 yang berarti lebih dari 1 dan kurang dari 10. Maka dapat disimpulkan bahwa seluruh variabel independen dalam penelitian ini tidak ditemukan gejala multikolinearitas atau korelasi antar variabel independen.

\section{Hasil Uji Heteroskedastisitas}

Tabel 10 : Hasil Uji Heteroskedastisitas (Uji Glejser)

\begin{tabular}{lccc}
\hline \multicolumn{1}{c}{ Variabel Bebas } & t-hit & Sig & Keterangan \\
\hline Herding $\left(\mathrm{X}_{1}\right)$ & 0,154 & 0,878 & Bebas Heterokedastisitas \\
Overconfidence $\left(\mathrm{X}_{2}\right)$ & 0,808 & 0,421 & Bebas Heterokedastisitas \\
\hline
\end{tabular}

a. Dependent Variable: RES2

Berdasarkan tabel hasil uji heteroskedastisitas diatas, dapat diketahui bahwa pada variabel herding memiliki nilai signifikansi 0,878 yang dimana lebih besar dari 0,05 . Dan pada variabel overconfidence memiliki nilai signifikansi 0,421 dimana lebih besar dari 0,05 atau $5 \%$. Maka dari itu, dapat disimpulkan bahwa model regresi tidak terjadi gejala heteroskedastisitas.

\section{Hasil Analisis Regresi Berganda dan Uji Goodness Of Fit}

Model regresi berganda dilakukan untuk menguji pengaruh dua atau lebih variabel independen terhadap satu variabel dependen. 
Tabel 11 : Hasil Uji Regresi Linear Berganda dan Uji Goodness Of Fit

\begin{tabular}{lcccc}
\hline & \multicolumn{4}{c}{ Unstandardized Coefficients } \\
\multicolumn{1}{c}{ Model } & B & Std. Error & t & Sig. \\
\hline (Constant) & 5,690 & 2,204 & 2,582 & 0,011 \\
Herding $\left(\mathrm{X}_{1}\right)$ & 0,037 & 0,070 & 0,527 & 0,599 \\
Overconfidence $\left(\mathrm{X}_{2}\right)$ & 0,704 & 0,075 & 9,403 & 0,000 \\
\hline
\end{tabular}

a. Dependent Variable: keputusan investasi

F-hit : 44.213

Sig-F : 0,000

Adj. $R^{2}: 0,508$

$\mathrm{N}: 96$

Berdasarkan tabel 11 diatas, dapat dilihat nilai adj. $\mathrm{R}^{2}$ pada model regresi diperoleh sebesar 0,508 atau $50,8 \%$. Hal tersebut membuktikan bahwa tingkat kemampuan variabel herding dan overconfidence memberikan informasi yang dibutuhkan untuk memprediksi variasi variabel keputusan investasi sebesar 50,8\%. Sedangkan sisanya sebesar 49,2\% diterangkan oleh faktor lain yang tidak dijelaskan dalam penelitian ini. Nilai F model adalah sebesar 44.213 dengan tingkat signifikansi 0,000. Apabila dilihat dari nilai signifikansi $F$ tersebut diperoleh bahwa nilai sig $F$ lebih kecil dari 0,05. Hal ini berarti bahwa variabel herding dan overconfidence dapat menjelaskan keputusan investasi.

Berdasarkan hasil uji pada tabel di atas, variabel herding memiliki nilai koefisien positif sebesar 0,037 namun nilai signifikansi melebihi 0,05 yakni sebesar 0,599. Serta nilai $\mathrm{t}$ dari variabel herding sebesar 0,527 yang berarti lebih kecil dari t tabel yang telah ditentukan yakni 1,984. Hal ini menyatakan bahwa variabel herding berpengaruh positif dan tidak signifikan terhadap keputusan investasi $\mathrm{H}_{1}$ ditolak. Sedangkan pada variabel overconfidence memiliki nilai koefisien positif sebesar 0,704 dan signifikansi dibawah 0,05 yakni sebesar 0,000 . Dan memiliki nilai t sebesar 9,403 yang berarti lebih besar dari t tabel yaitu 1,984. Hal tersebut menyatakan bahwa variabel overconfidence berpengaruh positif dan signifikan terhadap keputusan investasi $\mathrm{H}_{2}$ diterima.

\section{Pembahasan}

\section{Pengaruh Herding terhadap Keputusan Investasi}

Hasil dari penelitian ini menunjukan bahwa perilaku herding berpengaruh positif dan tidak signifikan terhadap keputusan investasi nasabah emas di Kantor Pegadaian Ungaran.Hal ini disebabkan responden pada penelitian ini cenderung mengandalkan informasi yang mereka dapat melalui teknologi internet sebagai bahan pengambilan keputusan investasinya. Hasil tersebut menunjukkan bahwa investor cenderung menerima informasi serta melakukan analisis dengan baik saat melakukan kegiatan investasi emas. Investor cenderung rasional, karena tidak terpengaruh oleh investor lain. Perilaku investor emas cenderung tidak mengikuti investor lain dalam pengambilan keputusan investasinya. Hal ini menunjukan bahwa para investor emas dalam mengambil keputusan investasinya berdasarkan informasi yang mereka dapat dan berdasarkan pertimbangan mereka masing-masing. Perilaku investor ini juga dapat terjadi karena ketersediaan informasi yang dirasa cukup sebagai dasar untuk mengambil keputusan investasinya, sehingga perilaku investor tidak hanya sekedar ikut-ikutan. Mayoritas investor dalam penelitian ini merupakan usia muda atau generasi milenial yang memang memiliki keunggulan dalam menyerap lebih banyak informasi secara cepat melalui 
teknologi yang mereka kuasai serta keahlian dalam menggali informasi yang banyak dan valid. Hal ini tercermin dari rata-rata responden yang mengetahui investasi emas melalui internet atau media sosial. Ditambah lagi dengan ketersediaan informasi yang cukup memadai, sehingga dapat dijadikan sebagai dasar pengambilan keputusan.

Berdasarkan penjabaran diatas dapat disimpulkan bahwa tidak adanya pengaruh yang signifikan antara herding terhadap keputusan investasi, hal tersebut sejalan dengan teori yang diungkapkan Setiawan et al,. (2018) dan Gozalie dan Anastasia (2015) yang menyatakan bahwa perilaku herding tidak berpengaruh terhadap pengambilan keputusan investasi.

\section{Pembahasan Pengaruh Overconfidence terhadap Keputusan Investasi}

Hasil penelitian ini menunjukan bahwa investor emas di Pegadaian Cabang Pembantu Ungarandipengaruhi oleh tingkat kepercayaan diri yang tinggi atau overconfidence dalam melakukan kegiatan investasi emas. Ketika investor memiliki tingkat percaya diri yang tinggi maka maka akan lebih berani dalam pengambilan keputusan investasinya, bahkan mengabaikan resiko yang mungkin ditimbulkan serta merasa investasi yang dilakukan tersebut akan menguntungkan dimasa yang akan datang. Hal tersebut tercermin pada jawaban responden bahwa mereka sangat yakin dengan pilihan investasi yang dilakukan, merasa memiliki kemampuan dan pengetahuan yang baik dalam berinvestasi, serta sangat yakin dengan pilihan investasi yang dilakukannya. Hasil ini sesuai dengan teori yang dikemukakan oleh Asri (2015) bahwa overconfidence menunjuk pada penilian seorang investor terhadap dirinya sendiri, dalam konteks ini investor menilai dirinya mempunyai kemampuan diatas rata-rata. Dengan tingkat overconfidence yang tinggi, membuat investor sangat yakin dengan laba yang akan diperoleh dari invetasinya, sehingga semakin besar pula investasi yang dilakukannya. Hasil penelitian ini sejalan dengan penelitian sebelumnya oleh Budiman (2020), Pradikasari dan Isbanah (2018), dan Fridana dan Asandimitra (2020) dimana overconfidence berpengaruh positif dan signifikan terhadap keputusan investasi emas.

\section{PENUTUP}

Berdasarkan pada data yang diperoleh maupun hasil analisis yang dilakukan, maka maka dapat ditarik kesimpulan mengenai pengaruh herding dan overconfidence terhadap keputusan investasi pada investor emas di Pegadaian Cabang Pembantu Ungaran sebagai berikut:

1. Herding berpengaruh positif dan tidak signifikan terhadap keputusan investasi emas. Halini disebabkan responden pada penelitian ini cenderung mengandalkan informasi yang merekadapat melalui teknologi internet yang memang mereka kuasai. Ditambah lagi dengan ketersediaan informasi yang cukup memadai, sehingga dapat dijadikan sebagai dasar pengambilan keputusan investasinya.

2. Overconfidence berpengaruh terhadap keputusan investasi emas. Hal ini disebabkan karena responden pada penelitian ini memiliki rasa percaya diri yang tinggi, sehinga menyebabkan overestimate terhadap kemampuannya dan underestimate terhadap resiko yang ada, yang padaakhirnya akan semakin banyak melakukan investasi pada emas.

Hasil penelitian ini diharapkan dapat membantu investor agar lebih bijak dalam menyikapi perilaku Herding dan Overconfidence khususnya dalam melakukan investasi disektor riil seperti emas. Penelitian ini juga masih memiliki keterbatasan dalam hal variabel independen, sehingga diharapkan pada penelitian selanjutnya dapat melakukan penelitian kembali terkait keputusan investasi, dengan memberikan model yang lebih 
akurat mengenai faktor-faktor yang mempengaruhi keputusan investasi. Adapun saran manajerial untuk Kantor Pegadaian Ungaran yaitu lebih memberikan gambaran seputar investasi dengan melakukan sosialisasi atau kebijakan strategis yang menekankan bahwa investasi pada emas merupakan investasi yang aman, mudah dilakukan dimanapun dan kapanpun, dan investasi yang murah sehingga dapat dijangkau oleh semua kalangan

\section{DAFTAR PUSTAKA}

Afriani, D., \& Halmawati. (2019). Pengaruh cognitive dissonance bias , overconfidence bias dan herding bias terhadap pengambilan keputusan investasi. Jurnal Eksplorasi Akuntansi, 1(4), 1650-1665. http://jea.ppj.unp.ac.id/index.php/jea/issue/view/14

Anum, \& Ameer, B. (2017). Faktor Perilaku dan Dampaknya pada Pengambilan Keputusan Investor Individual dan Kinerja Investasi: Investigasi Empiris dari Pasar Saham Pakistan.Jurnal Global Manjemen Dan Riset Bisnis, 17, 1-11.

Asri, M. (2015). Keuangan Keperilakuan (Edisi Pert). BPFE-Yogyakarta.

Bangun, V. L. (2020). Pengaruh Literasi Keuangan, Persepsi Risiko dan Overconfidence terhadap Keputusan Investasi (Studi Kasus pada Generasi Milenial di Yogyakarta). http://www.akrabjuara.com/index.php/akrabjuara/article/view/919

Barlian, P. D. E. (2016). Metodolodi Penelitian Kualitatif dan Kuantitatif.

Budiarto, A., \& Susanti. (2017). Pengaruh Financial Literacy, Overconfidence, Regret Aversion Bias, Dan Risk Tolerance Terhadap Keputusan Investasi (Studi pada investor PT. Sucorinvest Central Gani Galeri Investasi BEI Universitas Negeri Surabaya). Jurusan Manajemen Fakultas Ekonomi Universitas Negeri Surabaya, 05(02), 1-9.

Budiman, J. (2020). Pendekatan Perilaku Keuangan Terhadap Keputusan Investasi Emas. Profit, 14(01), 63-68. https://doi.org/10.21776/ub.profit.2020.014.01.7

Fridana, I. O., \& Asandimitra, N. (2020). Analisis Faktor Yang Memengaruhi Keputusan Investasi (Studi Pada Mahasiswi Di Surabaya). Jurnal Muara Ilmu Ekonomi Dan Bisnis, 4(2), 396. https://doi.org/10.24912/jmieb.v4i2.8729

Ghozali, I. (2018). Aplikasi Analisis Multivariate dengan Program IBM SPSS 25 (9th ed.). Badan Penerbit Universitas Diponegoro.

Gozalie, S., \& Anastasia, N. (2015). Pengaruh perilaku heuristics dan herding terhadap pengambilan keputusan investasi properti hunian. Finesta, 3(2), 28-32.

Jannah, W., \& Ady, S. U. (2017). Analisis Fundamental, Suku Bunga, Dan Overconfidence Terhadap Pengambilan Keputusan Investasi Pada Investor Di Surabaya. Jurnal Bisnis Dan Manajemen, 1(2), 138-155. https://doi.org/http://dx.doi.org/10.25139/ekt.v0i0.338

Kumar, S., \& Goyal, N. (2015). Behavioural biases in investment decision making - a systematic literature review. Systematic Literature Review. Qualitative Research in Financial Markets, 7(1), 88-108. https://doi.org/10.1108/QRFM-07-2014-0022

Nofsinger, J. R. (2016). The Psychology of Investing. In The Psychology of Investing. Taylor and Francis. https://doi.org/10.4324/9781315506579

Pradhana, R. W. (2018). Pengaruh Financial Literacy, Cognitive Bias, Dan Emotional 
Bias Terhadap Keputusan Investasi (Studi Pada Investor Galeri Investasi Universitas Negeri Surabaya). Jurusan Manajemen Fakultas Ekonomi Universitas Negeri Surabaya, 6(3), 108-117.

Pradikasari, E., \& Isbanah, Y. (2018). Pengaruh Financial Literacy, Illusion Of Control, Overconfidence, Risk Tolerance, Dan Risk Perceptionterhadap Keputusan Investasi PadaMahasiswa Di Kota Surabaya. Jurnal Ilmu Manajemen, 6(4), 424434.

Ramdani, F. N. (2018). Analisis Pengaruh Representativeness Bias Dan Herding Behavior Terhadap Keputusan Investasi (Studi Pada Mahasiswa Di Yogyakarta). Skripi Fakultas Ekonomi Universitas Islam Indonesia, 1-16.

Sarimatua, Y. R. (2017). Peran Psychological Factors Terhadap Pengambilan Keputusan Finansial (Studi Kasus Pada Perusahaan Kalrez Petroleum (Seram) Ltd.). Administrasi Bisnis Fakultas, 51(1), 105-114. https://media.neliti.com/media/publications/189710-ID- peran-psychologicalfactors-terhadap-pen.pdf

Setiawan, Y. C., Atahu, A. D. R., \& Robiyanto. (2018). Cognitive Dissonance Bias , Overconfidence Bias dan Herding Bias dalam Pengambilan Keputusan Investasi Saham. Jurusan Manajemen Fakultas Ekonomika Dan Bisnis Universitas Kristen Satya Wacana Salatiga, 1(1), 17-25. https://doi.org/26.82017/JKP.2017.001

Sugiyono. (2013). Metode Penelitian Kuantitatif Kualitatif dan R\&D (19th ed.). Alfabeta, CV.

Syahrum, \& Salim. (2014). Metode Penelitian Kuantitatif. In R. Ananda (Ed.), E-Book (1st ed.). Citapustaka Media.

Wulandari, D. A., \& Rr, I. (2014). Studi Experienced Regret, Risk Tolerance, OverconfidanceDan Risk Perception Pada Pengambilan Keputusan Investasi Dosen Ekonomi. Journal ofBusiness and Banking, 4(1), 55-66.

Www.bareksa.com. (n.d.). Harga Emas Lampaui Rpl Juta/gram, Begini Hasil Investasi Logam Mulia $10 \quad$ Tahun. Bareksa.Com. https://www.bareksa.com/berita/id/text/2020/08/ 05/harga-emas-lampaui-rp1jutagram-begini-hasil-investasi-logam-mulia-10- tahun/25459/news 